\title{
Effect of milking frequency and a-tocopherol plus selenium supplementation on sheep milk lipid composition and oxidative stability
}

\author{
E. Pulido, ${ }^{1}$ M. Fernández, ${ }^{1}$ N. Prieto, ${ }^{2}$ R. L. Baldwin VI, ${ }^{3}$ S. Andrés, ${ }^{1}$ S. López, ${ }^{1}$ and F. J. Giráldez ${ }^{1 *}$ \\ ${ }^{1}$ Instituto de Ganadería de Montaña, CSIC-Universidad de León, Finca Marzanas s/n, 24346 Grulleros, León, Spain \\ 'Lacombe Research and Development Centre, Agriculture and Agri-Food Canada, 6000 C\&E Trail, Lacombe, Alberta, T4L 1W1, Canada \\ ${ }^{3}$ Animal Genomics and Improvement Laboratory, USDA Agricultural Research Service, Beltsville, MD 20705
}

\section{ABSTRACT}

The aim of this research was to study the effect of milking frequency [once-daily milking (ODM) vs. twice-daily milking (TDM)] and antioxidant (AOX) supplementation on fatty acid (FA) profile and oxidative stability in sheep milk. Sixteen Assaf ewes were used; 8 did not receive any vitamin-mineral supplement (control), and the other 8 received an oral dose of 1,000 IU of $\alpha$-tocopherol and $0.4 \mathrm{mg}$ of Se daily. The experiment consisted of 2 consecutive periods; the first was 3 wk with TDM of both mammary glands. The second period was $8 \mathrm{wk}$ and consisted of ODM of one mammary gland and TDM of the other gland. All ewes were fed ad libitum the same total mixed ration from lambing and throughout the experiment. There were no differences in plasma or milk Se concentrations between control and AOX ewes. However, plasma and milk $\alpha$-tocopherol concentrations and AOX capacity were increased in ewes receiving the AOX supplement. Milk FA profile was practically unaffected after $21 \mathrm{~d}$ of AOX supplementation. However, after $77 \mathrm{~d}$, AOX supplementation increased the relative percentage of C16:0 and cis-9 C18:1 and reduced the proportions of some saturated FA with less than 16 carbons and cis-9 C12:1. Antioxidant supplementation had no effect on the proportions of conjugated linoleic acid or total polyunsaturated FA (PUFA) but decreased the proportion of trans-7, cis-9 C18:2 and increased that of n-6 C20:3. Once-daily milking did not affect $\alpha$-tocopherol, Se, or fat resistance to oxidation in milk. Total monounsaturated FA, cis-9 C16:1, and several cis and trans isomers of C18:1 were increased and total saturated FA were decreased in milk from ODM glands. Compared with TDM, ODM increased the proportions of cis-9,cis-12 $\mathrm{C} 18: 2$ and several isomers of $\mathrm{C} 18: 2$ and reduced those of cis-9,cis-12,cis-15 C18:3 and some PUFA of 20 and

Received July 27, 2018.

Accepted December 17, 2018.

*Corresponding author: j.giraldez@eae.csic.es
22 carbons, but total proportion of PUFA was unaffected. Once-daily milking and AOX supplementation modified milk FA profile, but the effects of ODM could be considered of little biological relevance for consumer health. Supplementing ewes with $\alpha$-tocopherol plus Se could be considered an effective strategy to improve plasma AOX status and reduce milk fat oxidation without substantial changes in the milk FA profile.

Key words: dairy sheep, $\alpha$-tocopherol, selenium, oxidative stability, milking frequency

\section{INTRODUCTION}

Milking routine is a major determinant of the total daily labor in dairy sheep farms. Sheep are usually milked twice daily, so omitting 1 milking daily reduces workload substantially and improves the quality of farmers' lives (Marnet and McKusick, 2001; Hervás et al., 2006). Several studies have evaluated the effects of milking frequency (MF) on milk production and its major chemical components (e.g., protein, fat, and lactose) and udder health (Nudda et al., 2002; Hervás et al., 2006; Castillo et al., 2008; Prieto et al., 2013; Stelwagen et al., 2013). However, little is known about MF effects on other milk characteristics, such as lipid composition or antioxidant (AOX) capacity, that have gained interest for their potential effects on consumer health (Savoini et al., 2016).

Extensive research over recent decades has aimed to identify strategies for improving milk fatty acid (FA) profile, mostly through dietary manipulation (Chilliard et al., 2006; Shingfield et al., 2013). Uptake of milk precursors and activity of key mammary enzymes involved in FA synthesis can be affected by MF (Hillerton et al., 1990; Farr et al., 1995; Bionaz and Loor, 2008). Some studies in dairy cows reported that reducing MF from twice-daily milking (TDM) to once-daily milking (ODM) does not modify milk FA profile (Chilliard et al., 2006; Guinard-Flament et al., 2007) or reduces the proportion of short-chain FA (SCFA) and free FA (Delamaire and Guinard-Flament, 2006; Wiking et al., 
2006). Other studies have examined the effects of increasing MF (2 vs. 3 or 4 milkings daily) and reported contradictory results, with either no significant effects on FA profile (Shields et al., 2011) or a reduction in PUFA (Wiking et al., 2006) or C24:0 and cis-9 C18:1 (Ferneborg et al., 2017) concentrations when MF is increased. The contradictory results reported in dairy cows could be related to factors modulating the effect of MF, such as nutritional status of the animal, diet composition, milking interval, short- or long-term effects, or gland characteristics. Moreover, the analytical methods used for FA analysis (number of FA determined, effect on individual FA or principal FA groups) may also affect the results observed. Few published studies have investigated the effects of MF on milk fat composition in dairy cows (Chilliard et al., 2006; Wiking et al., 2006; Guinard-Flament et al., 2007; Lindman, 2014; Dutreuil et al., 2016; Ferneborg et al., 2017), and to the best of our knowledge no data are available on these effects in sheep.

Regarding milk oxidative stability, it should be noted that increasing AOX activity improves milk shelf life and protects consumers against oxidative damage (Lindmark-Månsson and Akesson, 2000; Politis, 2012). An increased metabolic rate in dairy animals increases oxidative stress, reduces capabilities of the host's AOX defenses, and negatively affects milk AOX activity (Sordillo and Aitken, 2009; Tsiplakou et al., 2018). Thus, reducing MF has been proposed as a strategy to reduce oxidative stress and improve immune status (O'Driscoll et al., 2012). However, in high-yielding dairy ruminants, less frequent milking increases intramammary pressure, causing mechanical stress on the tight junctions and thus affecting their integrity and permeability (Bernier-Dodier et al., 2010; Stelwagen et al., 2013). Consequently, local inflammation is likely to occur, usually associated with oxidative stress, upregulation of acute-phase response and apoptosis-related genes, and increased SCC in milk (Piantoni et al., 2010; Lakic et al., 2011). Therefore, ODM may increase or reduce oxidative stress and milk AOX capacity, depending on the balance between anti- and pro-oxidant effects.

The AOX capacity of vitamin E (administered alone or in combination with Se) has been evaluated in dairy cattle and goats, examining the effects on milk production, composition, and oxidation (Focant et al., 1998; Tufarelli and Laudadio, 2011). Other studies have investigated lamb AOX status when dams were supplemented with vitamin E (Capper et al., 2005; Liesegang et al., 2008). As stated by Politis (2012), most of these studies provide evidence that vitamin E supplementation reduces milk oxidation, although opposite results have been also reported (Slots et al., 2007); hence, further investigation is warranted.
It can be hypothesized that supplementing the diet with AOX is an effective strategy for protecting the mammary tissue against oxidative stress, in particular when MF is reduced. However, no studies have tested the interaction between MF and AOX supplementation on milk fat composition and oxidation. Therefore, the aim of this work was to study the effects of MF (ODM vs. TDM) and $\alpha$-tocopherol plus Se supplementation on milk fat composition and oxidative stability in highyielding Assaf dairy ewes.

\section{MATERIALS AND METHODS}

\section{Animal Ethics}

The experiment was compliant with the Spanish legislation (Royal Decree 1201/2005) related to the protection of animals used for experimental and other scientific purposes. The experimental procedures were approved by the Institutional Animal Care and Use Committee of the Instituto de Ganadería de Montaña (Léon, Spain).

\section{Animals and Diets}

The experiment design was described in detail by Pulido et al. (2012). Sixteen high-yielding Assaf ewes in wk 4 of lactation were used in this study. Eight animals (control group) did not receive any extra vitamin-mineral supplement, and the other 8 animals (AOX treatment) were supplemented daily with an oral dose of 1,000 IU of DL- $\alpha$-tocopherol acetate (BASF, Burgbernheim, Germany) and $0.4 \mathrm{mg}$ of Se (sodium selenite anhydrous; Panreac, Barcelona, Spain). The AOX supplement was always administrated in the milking parlor immediately after the morning milking. Experimental groups were balanced according to BW (77.0 \pm 2.37 $\mathrm{kg})$, milk production $(2,548 \pm 119.7 \mathrm{~g} / \mathrm{d})$, left gland: right gland milk production ratio $(1.00 \pm 0.023)$, day of lactation $(26.6 \pm 1.51 \mathrm{~d})$, and cisternal milk production $(64 \pm 2.6 \%)$. All sheep were managed similarly and maintained under the same feeding system from parturition throughout the experiment, receiving a TMR ad libitum (Table 1). Diet was formulated to meet both vitamin E and Se requirements (NRC, 1985).

\section{Experimental Procedures}

The experiment consisted of 2 periods. In the first period ( $3 \mathrm{wk})$, both mammary glands of all ewes were milked twice daily at 0930 and $1930 \mathrm{~h}$. During the second period ( $8 \mathrm{wk}$ ), one mammary gland (gland A) was milked once daily in the morning and the other gland (gland B) was milked twice daily in the morning 
and evening. Each MF was randomly assigned to the glands. The first experimental period aimed to reinforce the AOX status of AOX ewes before different milking frequencies were applied.

Ewes were machine milked in a $1 \times 10$ low-line Casse system milking parlor with 10 milking stalls and 2 milking clusters. The milking machine (Alfa-Laval Iberia S.A., Madrid, Spain) was set at 120 pulsations/min in a $50: 50$ ratio at a vacuum of $36 \mathrm{kPa}$. The milking routine for the regular daily milking included teat cleaning, machine stripping (i.e., massaging the udder before removal of the teat cups), and teat dipping (Alfadine, DeLaval, Barcelona, Spain).

\section{Blood and Milk Sampling}

All ewes were blood sampled by jugular venipuncture in periods 1 (d 1, 14, and 21) and 2 (d 49 and 77) before administration of the daily ration. Blood samples were collected into Vacutainer tubes $(10 \mathrm{~mL}$; Becton Dickinson, Franklin Lakes, NJ) containing either sodium heparin or no anticoagulant. Blood samples collected in the sodium heparin tubes were immediately placed in ice water and centrifuged at $1,000 \times g$ for $10 \mathrm{~min}$ at $4^{\circ} \mathrm{C}$.

Table 1. Ingredients and chemical composition of the TMR $(\mathrm{g} / \mathrm{kg}$ of TMR fresh matter unless otherwise stated)

\begin{tabular}{lc}
\hline Item & Value \\
\hline Ingredient & \\
Dehydrated alfalfa & 300 \\
Barley grain & 230 \\
Corn grain & 120 \\
Soybean meal 44 & 480 \\
Oats & 70 \\
Cottonseed & 50 \\
Sugar beet pulp & 40 \\
Rapeseed meal & 30 \\
Sunflower meal & 30 \\
Molasses & 25 \\
Calcium carbonate & 13 \\
Sodium chloride & 5 \\
Wheat shorts & 3 \\
Mineral-vitamin premix ${ }^{1}$ & 4 \\
Chemical composition & \\
DM & 952 \\
CP & 169 \\
NDF & 285 \\
ADF & 155 \\
Ether extract & 42 \\
Ash & 86 \\
Vitamin E (IU/kg of TMR) & 36 \\
Se ( $\mu$ g/kg of TMR) & 152 \\
Thinl-vitain premix: vitam A & \\
\hline
\end{tabular}

${ }^{1}$ Mineral-vitamin premix: vitamin $\mathrm{A}(7,000 \mathrm{IU} / \mathrm{kg})$, vitamin $\mathrm{D}_{3}(1,400$ $\mathrm{IU} / \mathrm{kg}), \alpha$-tocopherol $(8 \mathrm{IU} / \mathrm{kg})$, copper sulfate pentahydrate $(2 \mathrm{mg}$ of $\mathrm{Cu} / \mathrm{kg}$ ), iron sulfate monohydrate (49 $\mathrm{mg}$ of $\mathrm{Fe} / \mathrm{kg}$ ), zinc oxide $(34 \mathrm{mg}$ of $\mathrm{Zn} / \mathrm{kg}$ ), manganese oxide (32 $\mathrm{mg}$ of $\mathrm{Mn} / \mathrm{kg}$ ), potassium iodide (2 $\mathrm{mg}$ of $\mathrm{I} / \mathrm{kg})$, cobalt carbonate monohydrate $(0.9 \mathrm{mg}$ of $\mathrm{Co} / \mathrm{kg})$, sodium selenite $(0.2 \mathrm{mg}$ of $\mathrm{Se} / \mathrm{kg})$.
The harvested plasma was then stored at $-80^{\circ} \mathrm{C}$ until required for $\alpha$-tocopherol and total AOX analyses. The samples in tubes with no anticoagulant were allowed to clot for $30 \mathrm{~min}$ at room temperature and centrifuged at $2,000 \times g$ for $15 \mathrm{~min}$ at $4^{\circ} \mathrm{C}$. The harvested serum was stored at $-20^{\circ} \mathrm{C}$ until used to measure Se.

Milk samples from each gland were taken in collection jars on d 21 (end of period 1) and 77 (end of period 2) at each milking according to the experimental design. In the case of TDM glands, aliquots (10\% of the milk yielded) were collected from each milking and then pooled and mixed in a single daily milk sample for each gland. All milk samples were stored at $-80^{\circ} \mathrm{C}$ for the corresponding analyses.

\section{Chemical Analyses}

Se and $\alpha$-Tocopherol Determinations. Plasma and milk samples were prepared (deproteinization, extraction, and purification) for determination of $\alpha$-tocopherol concentration. The analysis was conducted by the reverse-phase HPLC method described by Chauveau-Duriot et al. (2010) using a Waters LC Module I liquid chromatograph (Waters, Milford, MA) system (model 600 pump, model 715 autosampler, and model 486 spectrophotometric detector). The separation was performed on a Waters Symmetry C18 column $(5 \mu \mathrm{m}, 250 \times 4.6 \mathrm{~mm})$ with acetonitrile-methanol-dichloromethane (40:50:10 vol/vol/vol) as the mobile phase and at a flow rate of $1 \mathrm{~mL} / \mathrm{min}$. The extracts were analyzed by a UV detector with wavelength set at $292 \mathrm{~nm}$. Tocopheryl acetate and $\delta$-tocopherol were used as internal standards for quantification of $\alpha$-tocopherol in plasma and milk samples, respectively. Selenium content in serum and milk samples was determined by inductively coupled plasma MS using a Perkin-Elmer NexION 300D ICP-MS instrument (B'Hymer and Caruso, 2006).

Milk FA Profile. Fatty acid composition in milk fat was determined on milk samples collected on d 21 and 77. The rapid method described by Feng et al. (2004) and Luna et al. (2005) was used for milk fat separation. Briefly, milk samples $(\sim 90 \mathrm{~mL})$ were defrosted at $4^{\circ} \mathrm{C}$; the refrigerated raw milk samples were held at room temperature for $20 \mathrm{~min}$ and centrifuged at 15,150 $\times g$ for $30 \mathrm{~min}$ at $20^{\circ} \mathrm{C}$. The fat layer was removed, transferred to tubes, and centrifuged at $20,800 \times g$ for $30 \mathrm{~min}$ at $20^{\circ} \mathrm{C}$. Separated lipids (upper layer) were stored in amber vials, exposed to a stream of $\mathrm{N}_{2}$, and frozen at $-80^{\circ} \mathrm{C}$ until analysis. After methylation by base-catalyzed methanolysis of glycerides (ISO/IDF, 2002), FAME were analyzed by GC (Agilent $6890 \mathrm{~N}$ Network System, Palo Alto, CA), following the proce- 
dures described by Aldai et al. (2012). Sixty-six peaks were identified, and milk FA composition was expressed as grams per 100 grams of total FAME.

Plasma AOX Activity and Milk Oxidative Stability. Total AOX activity in plasma was measured using the AOX assay kit CS0790 (Sigma-Aldrich, St. Louis, MO) following the manufacturer's instructions. The total AOX activity was measured using 2,2'-azinobis-3-ethylbenzothiazoline-6-sulfonic acid as substrate and the analog trolox (6-hydroxy 2,5,7,8-tetramethylchroman-2-carboxylic acid) as the standard (Re et al., 1999) so that the scavenging activity in plasma was expressed as trolox equivalent AOX capacity.

The oxidative stability in milk samples collected on d 21 and 77 was tested by the Rancimat method. Briefly, the volatile degradation products were trapped in distilled water and measured conductometrically. The induction times were determined from curves of the conductivity against time using a Metrohm 679 Rancimat (Metrohm AG, Herisau, Switzerland) following AOCS Official Method Cd 12b-92 (Firestone, 2011), with a test sample of $2.5 \mathrm{~g}$ held at $120^{\circ} \mathrm{C}$ and a flow rate of purified air of $20 \mathrm{~L} / \mathrm{h}$.

\section{Statistical Analysis}

Data of concentrations of $\alpha$-tocopherol and Se and AOX capacity in plasma were subjected to repeatedmeasures analysis using the MIXED procedure of SAS (SAS Institute Inc., Cary, NC). The statistical model included the fixed effects of AOX supplement (control vs. AOX supplementation), period (before and after MF change), day within the period (period 1: d 14 and 21; period 2: $\mathrm{d} 49$ and 77 ), and supplement $\times$ period interaction. The ewe was nested within the supplement and considered as the experimental unit to test the effect of
AOX treatment. The mean square of the period $\times$ ewe (supplement) interaction was used for the denominator of the $F$ statistic to test the effects of period and the interaction between AOX supplement and period.

In repeated-measures analysis, different covariance matrixes were evaluated on the basis of Schwarz's Bayesian information criterion. When plasma data were analyzed, values recorded at d 1 were initially used as covariate, being removed from the model when their effect was not significant $(P>0.05)$.

Milk FA profile, $\alpha$-tocopherol and Se concentrations in milk, and lipid oxidative stability data were analyzed within each experimental period (periods 1 and 2) including the fixed effects of AOX supplement (control vs. AOX), gland (equivalent to MF), and their interaction (supplement $\times$ period) in the model. The effect of the supplement was tested against the ewe nested to treatment. The remaining effects were tested against the residual error.

\section{RESULTS}

Antioxidant supplementation did not affect $(P>$ 0.05 ) daily DMI (on average $3.35 \pm 0.048 \mathrm{~kg}$ of $\mathrm{DM} /$ ewe). Consequently, daily intakes of Se $(510 \mu \mathrm{g} /$ ewe $)$ and $\alpha$-tocopherol (121 IU/ewe) from feed were similar for control and AOX groups.

\section{Se and a-Tocopherol Concentrations and AOX Capacity in Plasma}

The mean values of $\alpha$-tocopherol and Se concentration in plasma for each treatment and experimental period are shown in Table 2. Plasma $\alpha$-tocopherol concentration was significantly $(P<0.05)$ greater for the AOX group than for the control group in both periods.

Table 2. Concentrations of $\alpha$-tocopherol and Se and antioxidant capacity in plasma in control and supplemented dairy ewes

\begin{tabular}{|c|c|c|c|c|c|c|c|c|c|}
\hline \multirow[b]{2}{*}{ Item } & \multicolumn{2}{|c|}{$\frac{\text { AOX }}{\text { supplementation }^{1}}$} & \multicolumn{2}{|c|}{ Period $^{2}$} & \multirow[b]{2}{*}{$\mathrm{SED}_{\mathrm{S}}^{3}$} & \multirow[b]{2}{*}{$\mathrm{SED}_{\mathrm{P}}^{4}$} & \multicolumn{3}{|c|}{ Level of significance } \\
\hline & Control & AOX & 1 & 2 & & & $\mathrm{~S}$ & Period & $\mathrm{S} \times$ period \\
\hline $\begin{array}{l}\text { Plasma } \alpha \text {-tocopherol }(\mathrm{IU} / \mathrm{L}) \\
\text { Plasma Se }(\mu \mathrm{g} / \mathrm{L}) \\
\text { Plasma antioxidant capacity }\left(\mathrm{mMET}^{5} / \mathrm{L}\right)\end{array}$ & $\begin{array}{l}0.920^{\mathrm{a}} \\
144.9 \\
0.135^{\mathrm{a}}\end{array}$ & $\begin{array}{l}1.563^{\mathrm{b}} \\
147.5 \\
0.159^{\mathrm{b}}\end{array}$ & $\begin{array}{l}1.338^{\mathrm{b}} \\
153.9^{\mathrm{b}} \\
0.156^{\mathrm{b}}\end{array}$ & $\begin{array}{c}1.146^{\mathrm{a}} \\
138.4^{\mathrm{a}} \\
0.133^{\mathrm{a}}\end{array}$ & $\begin{array}{l}0.1159 \\
8.85 \\
0.0116\end{array}$ & $\begin{array}{l}0.0780 \\
2.69 \\
0.0062\end{array}$ & $\begin{array}{r}<0.001 \\
0.776 \\
0.030\end{array}$ & $\begin{array}{l}0.027 \\
0.011 \\
0.002\end{array}$ & $\begin{array}{l}0.581 \\
0.318 \\
0.538\end{array}$ \\
\hline $\begin{array}{l}\text { a,b Means within the same row and for each } \\
{ }^{1} \text { Control = no additional antioxidant supp } \\
\text { ments. } \\
{ }^{2} \text { Period } 1=\text { d } 1 \text { to } 21 \text { (both glands were } \mathrm{m} \\
\text { twice daily). } \\
{ }^{3} \text { Standard error of the difference for antiox } \\
{ }^{4} \text { Standard error of the difference for perioc } \\
{ }^{5} \text { Millimoles Trolox equivalent. }\end{array}$ & $\begin{array}{l}\text { source of } \\
\text { lementatio } \\
\text { ailked twic } \\
\text { xidant sup } \\
\text { d effect. }\end{array}$ & $\begin{array}{l}\text { ariation } \\
\text { AOX }=e \\
\text { daily); pe }\end{array}$ & $\begin{array}{l}\text { suppleme } \\
2=\mathrm{d} 22 \mathrm{t} \\
\text { effeceive } \\
\text { effect. }\end{array}$ & $\begin{array}{l}\text { tation or } \\
\text { daily } 1,0 \\
77 \text { (one g }\end{array}$ & $\begin{array}{l}\text { riod) wit } \\
\text { IU of } \alpha \\
\text { nd was } 1\end{array}$ & $\begin{array}{l}\text { differe } \\
\text { cophe } \\
\text { lked or }\end{array}$ & $\begin{array}{l}\text { superse } \\
\text { and } 0.4 \\
\text { daily a }\end{array}$ & $\begin{array}{l}\text { ts diffe } \\
g \text { of Se } \\
\text { the ot }\end{array}$ & $\begin{array}{l}(P<0.05) \text {. } \\
\text { above require- }\end{array}$ \\
\hline
\end{tabular}


There were not significant differences $(P>0.05)$ in serum Se concentrations because of AOX supplementation in any period (Table 2).

Plasma AOX capacity did not differ between treatments (control vs. AOX) at the beginning of the experiment (d 1 of period 1; data not shown), but thereafter it was greater $(P<0.01)$ for ewes receiving the AOX supplement compared with control sheep in both periods (Table 2). Plasma AOX capacity and $\alpha$-tocopherol and Se concentrations decreased $(P<0.05)$ in period 2 compared with period 1 , and this effect was independent of the AOX supplementation $(P>0.05$ for the interaction).

\section{Milk Composition and Oxidative Stability}

Time required for milk fat oxidation and $\alpha$-tocopherol content were significantly $(P<0.05)$ increased in milk from AOX supplemented sheep compared with control sheep in both periods (Table 3), whereas Se content was unaffected by AOX supplementation $(P>0.05)$. There were no differences $(P>0.05)$ between glands in $\alpha$-tocopherol and Se content in milk or its resistance to oxidation during period 1 (TDM in both glands) or period 2 (ODM vs. TDM).

\section{Milk FA Profile}

On d 21 (end of first experimental period), effects of AOX supplementation on milk FA were significant $(P$ $<0.05$ ) only for $\mathrm{C} 22: 0$ (0.08 vs. $0.06 \%$ of total FA for control and AOX ewes, respectively) and the sum of cis9,trans-12 C18:2 + trans-8,cis-13 C18:2 (0.12 vs. 0.14\% of total FA for control and AOX ewes, respectively). On d 77 (Table 4), AOX supplementation reduced $(P<$ $0.05)$ the proportion of the sum of FA with less than 16 carbons and increased $(P<0.05)$ that of longer chain FA ( $\geq 16$ carbons). Supplementation with AOX did not affect $(P>0.05)$ the relative abundance of total SFA, although the percentages of $\mathrm{C} 6: 0, \mathrm{C} 8: 0, \mathrm{C} 10: 0$, and $\mathrm{C} 12: 0$ were reduced and that of $\mathrm{C} 16: 0$ was increased in milk from AOX-supplemented ewes. Regarding MUFA, proportions of cis-9 C18:1 increased and those of cis-9 C12:1 decreased $(P<0.05)$ as a result of dietary AOX supplementation (Table 4). Antioxidant supplementation had no effect on total PUFA $(5.99 \pm 0.117 \%)$ or conjugated C18:2 $(0.91 \pm 0.048 \%)$ but decreased $(P$ $<0.05)$ the proportion of trans-7, cis-9 C18:2 and increased that of n-6 C20:3 (Table 4).

As expected, on d 21 with TDM in both glands, there were no significant $(P>0.05)$ differences between glands (both TDM) in FA composition. Only marginal differences were observed in few minor FA, specifically cis-9 $\mathrm{C} 16: 1$ (0.61 vs. $0.62 \%$ of total $\mathrm{FA}$ ), C18:0 iso (0.054 vs. $0.056 \%$ of total FA), and cis-9, cis- 15 C18:2 (0.022 vs. $0.024 \%$ of total FA).

On d 77 of the experiment, when one gland was milked once a day and the other twice a day, there were significant $(P<0.05)$ differences between glands in several of the FA determined (Table 4). The proportion of total FA shorter than 16 carbons was not affected by MF $(P>0.05)$, but that of C16 FA was increased and that of FA longer than 16 carbons decreased in milk fat from TDM glands compared with ODM glands. Relative abundance of SFA was slightly reduced $(P<0.05)$ with ODM compared with TDM, and small changes

Table 3. Effect of antioxidant supplementation and milking frequency on $\alpha$-tocopherol and Se concentrations and oxidative stability in milk

\begin{tabular}{|c|c|c|c|c|c|c|c|c|c|}
\hline \multirow[b]{2}{*}{ Item } & \multicolumn{2}{|c|}{ AOX supplementation ${ }^{1}$} & \multicolumn{2}{|c|}{ Milking frequency $^{2}$} & \multirow[b]{2}{*}{$\mathrm{SED}_{\mathrm{S}}{ }^{3}$} & \multirow[b]{2}{*}{$\mathrm{SED}_{\mathrm{MF}}^{4}$} & \multicolumn{3}{|c|}{ Level of significance } \\
\hline & Control & AOX & $\mathrm{A}$ & $\mathrm{B}$ & & & $\mathrm{S}$ & MF & $\mathrm{S} \times \mathrm{MF}$ \\
\hline \multicolumn{10}{|l|}{ Period 1} \\
\hline$\alpha$-Tocopherol (IU/kg) & $1.33^{\mathrm{a}}$ & $2.09^{\mathrm{b}}$ & 1.61 & 1.80 & 0.349 & 0.162 & 0.005 & 0.119 & 0.063 \\
\hline $\mathrm{Se}(\mu \mathrm{g} / \mathrm{kg})$ & 26.5 & 27.5 & 27.5 & 26.5 & 1.650 & 0.530 & 0.496 & 0.676 & 0.963 \\
\hline Oxidative stability (h) & $2.89^{\mathrm{a}}$ & $4.81^{\mathrm{b}}$ & 3.67 & 4.03 & 0.430 & 0.370 & $<0.001$ & 0.341 & 0.412 \\
\hline \multicolumn{10}{|l|}{ Period 2} \\
\hline Oxidative stability (h) & $5.36^{\mathrm{a}}$ & $7.23^{\mathrm{b}}$ & 6.09 & 6.50 & 1.870 & 0.390 & 0.002 & 0.136 & 0.263 \\
\hline
\end{tabular}

\footnotetext{
${ }^{\mathrm{a}, \mathrm{b}}$ Means within the same row and for each source of variation (AOX supplementation or milking frequency) with different superscripts differ $(P<0.05)$.

${ }^{1}$ Control $=$ no additional antioxidant supplementation; AOX $=$ each ewe received daily 1,000 IU of $\alpha$-tocopherol and 0.4 mg of Se above requirements.

${ }^{2}$ In period 1 (d 1-21), both glands A and B were milked twice daily. In period 2 (d 22-77), gland A was milked once daily and gland B was milked twice daily.

${ }^{3}$ Standard error of the difference for antioxidant supplementation (S) effects.

${ }^{4}$ Standard error of the difference for milking frequency (MF) effects.
} 
Table 4. Effect of antioxidant supplementation and milking frequency on milk fatty acid (FA) profile (g of each FA/100 g of FAME)

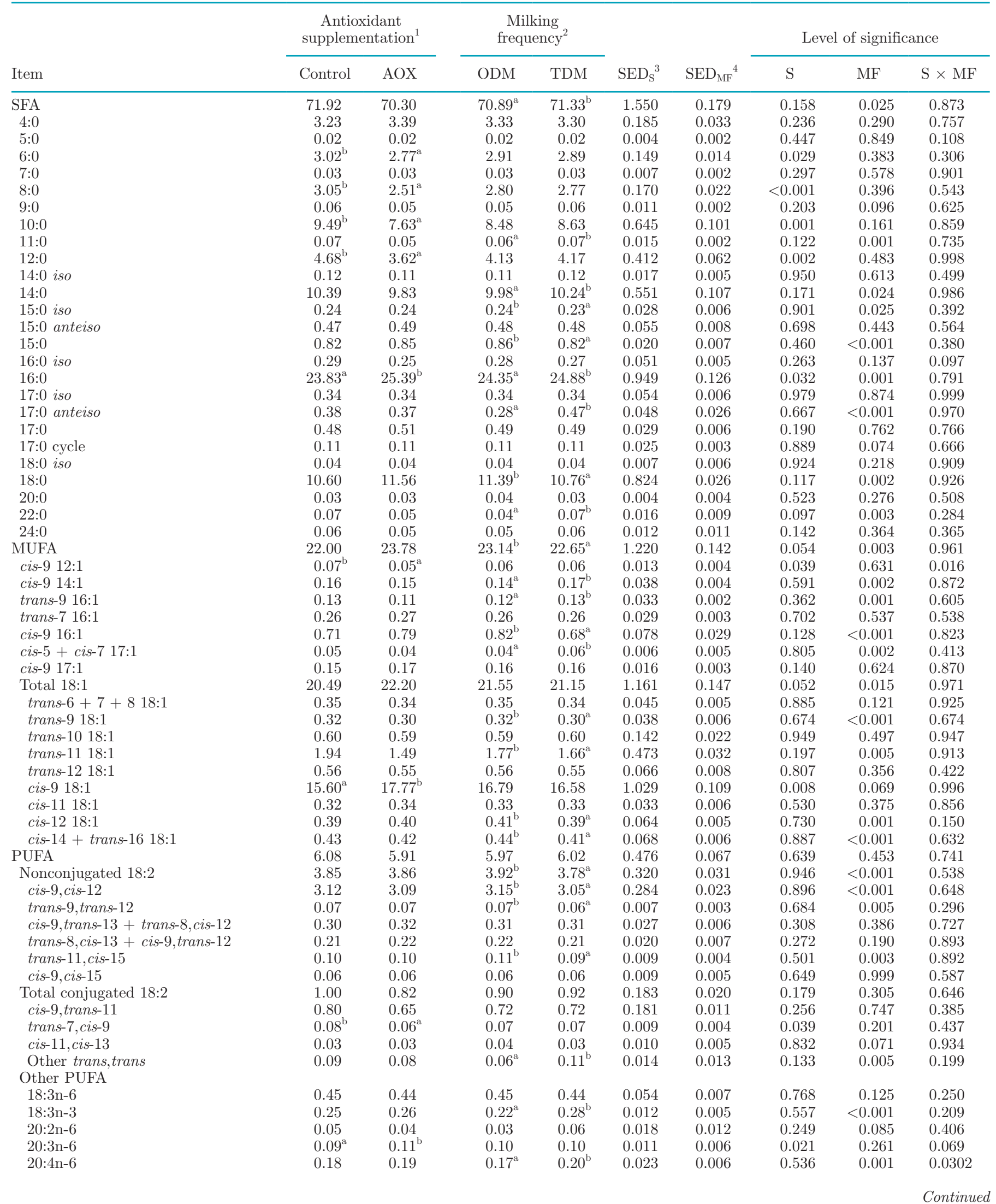


Table 4 (Continued). Effect of antioxidant supplementation and milking frequency on milk fatty acid (FA) profile (g of each FA/100 g of FAME)

\begin{tabular}{|c|c|c|c|c|c|c|c|c|c|}
\hline \multirow[b]{2}{*}{ Item } & \multicolumn{2}{|c|}{$\begin{array}{c}\text { Antioxidant } \\
\text { supplementation }^{1}\end{array}$} & \multicolumn{2}{|c|}{$\begin{array}{l}\text { Milking } \\
\text { frequency }^{2}\end{array}$} & \multirow[b]{2}{*}{$\mathrm{SED}_{\mathrm{S}}{ }^{3}$} & \multirow[b]{2}{*}{$\mathrm{SED}_{\mathrm{MF}}^{4}$} & \multicolumn{3}{|c|}{ Level of significance } \\
\hline & Control & $\mathrm{AOX}$ & ODM & TDM & & & $\mathrm{S}$ & MF & $\mathrm{S} \times \mathrm{MF}$ \\
\hline $22: 2 n-6$ & 0.06 & 0.07 & $0.05^{\mathrm{a}}$ & $0.08^{\mathrm{b}}$ & 0.018 & 0.012 & 0.581 & 0.021 & 0.868 \\
\hline $22: 5 n-3$ & 0.08 & 0.08 & 0.08 & 0.09 & 0.012 & 0.005 & 0.550 & 0.253 & 0.998 \\
\hline \multicolumn{10}{|l|}{ Summation } \\
\hline $\mathrm{OBCFA}^{5}$ & 3.34 & 3.38 & 3.29 & 3.43 & 0.248 & 0.086 & 0.824 & 0.064 & 0.749 \\
\hline \multicolumn{10}{|l|}{ Desaturation ratios } \\
\hline $\mathrm{RA} /(\mathrm{RA}+\mathrm{VA})^{6}$ & 0.29 & 0.30 & $0.29^{\mathrm{a}}$ & $0.30^{\mathrm{b}}$ & 0.021 & 0.004 & 0.251 & 0.010 & 0.155 \\
\hline C14:1/(C14:0 + C14:1) & 0.01 & 0.01 & $0.01^{\mathrm{a}}$ & $0.02^{\mathrm{b}}$ & 0.002 & 0.001 & 0.946 & 0.004 & 0.719 \\
\hline $\mathrm{C} 16: 1 /(\mathrm{C} 16: 0+\mathrm{C} 16: 1)$ & 0.04 & 0.04 & $0.05^{\mathrm{b}}$ & $0.04^{\mathrm{a}}$ & 0.004 & 0.006 & 0.961 & $<0.001$ & 0.682 \\
\hline $\mathrm{C} 18: 1 /(\mathrm{C} 18: 0+\mathrm{C} 18: 1)$ & 0.66 & 0.66 & $0.65^{\mathrm{a}}$ & $0.66^{\mathrm{b}}$ & 0.021 & 0.002 & 0.919 & 0.004 & 0.889 \\
\hline
\end{tabular}

$\overline{\mathrm{a}, \mathrm{b}}$ Means within the same row and for each source of variation (AOX supplementation or milking frequency) with different superscripts differ $(P<0.05)$.

${ }^{1}$ Control $=$ no additional antioxidant supplementation; AOX = each ewe received daily 1,000 IU of $\alpha$-tocopherol and 0.4 mg of selenium above requirements.

${ }^{2} \mathrm{ODM}=$ gland milked once daily; TDM = gland milked twice daily.

${ }^{3}$ Standard error of the difference for antioxidant supplementation (S) effect.

${ }^{4}$ Standard error of the difference for milking frequency (MF) effects.

${ }^{5}$ Odd- and branched-chain fatty acids $=$ sum of iso $\mathrm{C} 14: 0, \mathrm{C} 15: 0$, iso $\mathrm{C} 15: 0$, anteiso $\mathrm{C} 15: 0$, iso C16:0, C17:0, iso C17:0, anteiso C17:0, cis-9 17:1, and cis-5 + cis-7 17:1.

${ }^{6} \mathrm{RA}=$ rumenic acid, cis-9,trans-11 C18:2. VA = vaccenic acid, trans-11 C18:1.

were observed in some specific SFA, increasing (C15:0, $\mathrm{C} 15: 0$ iso, and $\mathrm{C} 18: 0)$ or decreasing (C11:0, C14:0, C16:0, C17:0 anteiso, and C22:0) their proportions in ODM milk. The sum of odd- and branched-chain FA was similar $(P>0.05)$ in milk fat from ODM and TDM glands (3.3 vs. $3.4 \mathrm{~g} / 100 \mathrm{~g}$ of FAME, respectively). In contrast, MUFA increased $(P<0.05)$ in milk from ODM glands because of the increase in cis-9, C16:1, and several cis and trans isomers of C18:1 (trans-9, trans-11, and cis-12). Total proportion of PUFA was not significantly $(P>0.05)$ affected by MF, although cis-9,cis-12 C18:2 and several C18:2 isomers (trans9,trans-12 and trans-11,cis-15) increased $(P<0.05)$, whereas cis-9,cis-12,cis-15 C18:3 and some PUFA with 20 or 22 carbons decreased $(P<0.05)$ in milk fat from ODM compared with TDM glands.

\section{DISCUSSION}

\section{Plasma Concentrations of $\alpha$-Tocopherol and Se}

Both $\alpha$-tocopherol and Se concentrations in plasma observed at the beginning of the experimental period can be considered normal and above deficiency thresholds (Stowe and Herdt, 1992; McDowell et al., 1996). As expected, the plasma concentration of $\alpha$-tocopherol was higher in AOX ewes than in control ewes, most likely derived from a greater input of $\alpha$-tocopherol ingested with the supplement, although not all vitamin $\mathrm{E}$ ingested is absorbed in the gastrointestinal tract (Alderson et al., 1971; Chikunya et al., 2004).

Serum concentration of Se is considered a good indicator of the Se status of the animal, and the values observed in this study were within a physiological range (Davis et al., 2008; Van Ryssen et al., 2013). In contrast with $\alpha$-tocopherol, Se concentration in serum was unaffected by AOX supplementation. Some studies have reported increased serum concentrations of Se in sheep in response to dietary supplementation of inorganic Se, with levels of sodium selenite supplementation similar to (Kumar et al., 2008) or greater than (Davis et al., 2008; Alhidary et al., 2015) that used in the current study. Nevertheless, in agreement with our study, Cristaldi et al. (2005) did not observe changes in serum Se concentration in wether lambs fed diets with either 0.2 or $2 \mathrm{mg}$ of Se (as selenite) $/ \mathrm{kg}$ after $16 \mathrm{wk}$ of supplementation. It must be taken into account that in the present experiment daily Se supplementation represented an increase of only $122 \mu \mathrm{g} / \mathrm{kg}$ of DM above the content of the basal diet, and it is known that inorganic Se is poorly absorbed in ruminants (Whanger et al., 1968). Moreover, starch-rich diets, such as that used in the current experiment, facilitate the conversion of inorganic Se into insoluble forms (Whanger et al., 1968). 
Both $\alpha$-tocopherol and Se concentrations in blood decreased in period 2 compared with period 1. Reduction in plasma $\alpha$-tocopherol concentration seems to be related to an increased transfer to milk. However, this explanation would not be adequate to entirely explain the observed decline in Se concentration. Selenium is considered a negative acute-phase reactant, and its serum concentration is decreased in many inflammatory conditions, probably linked to reductions in plasma selenoprotein-P fractions and glutathione peroxidase (Galloway et al., 2000). Reducing MF may initiate an inflammatory reaction, inducing an acute-phase response and modifying production of specific proinflammatory cytokines, such as serum amyloid A or a tumor necrosis factor (Piantoni et al., 2010; Lakic et al., 2011). Therefore, reduction in plasma Se concentration may be associated with an inflammatory response caused by the reduction in MF when ODM was applied to one of the glands after TDM. Data from the current study previously reported by Pulido et al. (2012) showed that SCC increased in the milk from the ODM gland (4.84 vs. $5.14 \log$ units of SCC for TDM and ODM glands, respectively; $P<0.05$ ), which would be compatible with an inflammatory response as reported in other studies (Nudda et al., 2002; Castillo et al., 2008).

\section{Milk Composition}

As reported in our previous publication (Pulido et al., 2012), milk yield and composition (fat and protein contents) were not affected by AOX supplementation. Nevertheless, as expected, $\alpha$-tocopherol concentration increased in milk of the AOX ewes, although the difference between groups in the daily output of $\alpha$-tocopherol in milk (2.0 and $3.2 \mathrm{IU} / \mathrm{d}$ for periods 1 and 2, respectively) represented less than $0.3 \%$ of the dietary supplementation. These results are in agreement with previous studies confirming that content of vitamin $\mathrm{E}$ in milk is related to dietary supply, although the transfer rate is rather low (Krukovsky and Loosli, 1952; Charmley and Nicholson, 1994; Vagni et al., 2011).

In contrast to $\alpha$-tocopherol, milk Se content was not affected by the oral supplementation. Previous studies have reported that Se concentration in milk can be increased or decreased when inorganic Se intake increased (Givens et al., 2004; Ceballos et al., 2009). Based on a meta-analysis, Ceballos et al. (2009) concluded that milk Se concentration cannot be predicted from Se intake when Se supplementation was less than $5 \mathrm{mg} / \mathrm{d}$ in dairy cows (equivalent to about $7-8 \mu \mathrm{g} / \mathrm{kg}$ of BW). In our study, the estimated daily dietary Se intake was on average 6 and $11 \mu \mathrm{g} / \mathrm{kg}$ of BW in control and AOX ewes, respectively, but this increase was not enough to cause differences between treatments in plasma Se concentration.

Omitting 1 milking daily reduced milk yield (Pulido et al., 2012) but had no effect on $\alpha$-tocopherol or Se milk concentrations. Transfer routes from blood to milk for both $\alpha$-tocopherol and Se are not completely understood (Hill et al., 2014), but our results suggest that gland uptake of both components was adjusted to milk yield. Mammary uptake of nutrients depends on blood flow and metabolic activity, and both decrease with less frequent milking (Guinard-Flament et al., 2011).

Compared with TDM, ODM did not affect milk fat content but decreased fat yield (Pulido et al., 2012). In general, milk FA profile was similar to that observed in earlier studies in Assaf dairy ewes (Gómez-Cortés et al., 2008). Both MF and AOX supplementation affected milk FA profile. However, the AOX supplementation $\times$ MF interaction was not statistically significant, suggesting that there were no additive or counteracting effects between both factors. The nutritional relevance of ODM effects on lipid composition can be considered quantitatively questionable because the magnitude of the effects was rather minor, which is in line with earlier publications comparing different milking frequencies in dairy cows (Wiking et al., 2006; Lindman, 2014; Ferneborg et al., 2017). To the best of our knowledge, no studies have been published in sheep.

Omitting 1 daily milking reduced the relative abundance of C16:0 and increased that of total FA with more than 16 carbons, with no effect on the sum of FA with less than 16 carbons. In contrast to our results, Delamaire and Guinard-Flament (2006) reported a decrease in SCFA (C4 to C10) when MF was reduced, which could be related to a decreased transfer of nutrients to the mammary gland and activity of enzymes involved in de novo synthesis of FA (Wilde and Knight, 1990; Delamaire and Guinard-Flament, 2006).

It has been proposed that ODM does not affect milk FA profile when dairy cows are in positive energy balance (Chilliard et al., 2006). As the energy balance becomes negative, the proportion of cis-9 C18:1 in milk is increased and that of SCFA and medium-chain FA is reduced because of increased mammary uptake of circulating long-chain FA (LCFA) from body fat mobilization (Chilliard et al., 2006). In our study, ewes would be in a positive energy balance as BW increased during the trial (total weight gain of $5.4 \pm 1.27$ and $4.3 \pm$ $1.45 \mathrm{~kg}$ /ewe for control and AOX groups, respectively), explaining the lack of effect on SCFA and cis-9 C18:1. The proportions of several isomers of C18:1 (trans-9, trans-11, trans-16, cis-12, and cis-14) were increased, and hence total MUFA was also increased, in ODM milk. Some of these FA, such as trans-11 C18:1, are 
produced by ruminal biohydrogenation (Mosley et al., 2002; Wallace et al., 2007; Shingfield et al., 2013). The supply of LCFA would be similar to both glands given the unilateral milking applied, but total milk fat synthesis and energy demand for milk would be reduced in ODM glands, and thus the flow of LCFA supply expressed in relative terms (g of LCFA supply/g of milk fat) would be increased in the ODM gland. In the case of cis-9 C18:1, any increased relative flow would be offset by a decrease in the desaturation rate of C18:0. Reduction in most desaturation rates could be related to a lower metabolic activity in ODM glands (Alex et al., 2015), although the desaturation of C16:0 was slightly increased, explaining the increase of cis-9 C16:1 at the expense of a decrease in C16:0.

When increasing MF (2 vs. 3 or 4 times/d), Lindman (2014) and Wiking et al. (2006) reported a reduction in PUFA content in milk. Other studies (Chilliard et al., 2006; Guinard-Flament et al., 2007) did not find changes in milk FA profile when MF was reduced from twice to once daily. No differences in total PUFA related to MF were found in our study, but the proportions of cis-9,cis-12 C18:2, cis-9,cis-12,cis-15 C18:3, and several isomers of conjugated C18:2 increased when the MF was decreased. Conversely, the proportions of most of the FA with more than 18 carbons decreased, suggesting a depressed metabolic activity in the mammary gland. In fact, most of the calculated desaturation rates declined with ODM, which is in line with previously reported downregulation of several genes involved in the lipid metabolism induced by omitting 1 milking daily (Boutinaud et al., 2013).

In agreement with Dutreuil et al. (2016), the relative percentage of odd- and branched-chain FA in milk fat was unaffected by MF. Most of the milk odd- and branched-chain FA are derived from microbial mass leaving the rumen and thus are mainly related to feed intake and diet composition (Vlaeminck et al., 2016).

The proportions of SCFA and medium-chain FA (with $<16$ carbons) were reduced and those of LCFA, in particular C16:0 and cis-9 C18:1, were increased with AOX supplementation. These results are in agreement with those of Al-Mabruk et al. (2004), who observed a reduction in the milk content of several SCFA and medium-chain FA and an increase in the total C18:1 (excluding vaccenic acid) in response to vitamin E supplementation. Vázquez-Añón et al. (2008) also observed a reduction in the proportion of total SCFA and an increase in that of cis-9 C18:1 upon AOX supplementation with ethoxyquin and butylated hydroxytoluene. On the contrary, Manso et al. (2016) reported an increase of SFA and a decrease of MUFA in response to vitamin E supplementation without Se. According to
Liu et al. $(2008,2013)$, the effect of vitamin $\mathrm{E}$ on milk FA profile follows a dose-response relationship and can be influenced by Se supplementation.

De novo synthesis of SCFA synthesis depends on plasma concentration of acetate and $\mathrm{BHB}$ and is downregulated by increasing plasma concentration of LCFA through the activity of the acetyl CoA carboxylase (Chilliard et al., 2000; Loften et al., 2014). As control and AOX animals were fed the same diet and there were no differences in either feed intake or BW, no difference would be expected in plasma LCFA. It has been suggested that digestive utilization of lipids can be improved by AOX supplementation, increasing absorption of LCFA (Taheri et al., 2018). Other studies have not found any effect of vitamin $\mathrm{E}$ or Se on fat digestibility (Kumar et al., 2008; Khodamoradi et al., 2013), and thus other mechanisms could be involved. Vázquez-Añón et al. (2008) suggested an oxidative protection of cis-9 C18:1 in feed to explain the increase in the proportion of this FA in milk in response to AOX supplementation.

Some studies suggest that vitamin E might modify ruminal FA biohydrogenation, preventing the trans-10 shift associated with milk fat depression caused by oil supplementation or grain-rich diets (Bauman and Griinari, 2003; O'Donnell-Megaro et al., 2012). In the current experiment, however, AOX supplementation did not affect trans-10 C18:1 or trans-11 C18:1 in milk. Concentration of trans-10 C18:1 seems to be inversely related to milk fat content (Bauman and Griinari, 2001; Pottier et al., 2006), but, in the current study, fat content was unaffected by AOX supplementation ( $\mathrm{Pu}-$ lido et al., 2012). No differences were observed either in milk conjugated C18:2 content or in FA desaturation related to AOX supplementation, in agreement with other studies in dairy cows in which cis-9,trans-11 C18:2 (O'Donnell-Megaro et al., 2012) or the activity of $\Delta^{9}$-desaturase enzyme (Berthelot et al., 2014) were not affected by vitamin E supplementation.

It should be emphasized that AOX supplementation affected milk FA profile only in the second period, suggesting that more than $21 \mathrm{~d}$ of supplementation would be necessary to promote significant changes in milk lipid composition. In fact, although effects of AOX supplementation on $\alpha$-tocopherol concentration and AOX capacity in milk were already significant during the first period, the differences were amplified in the second period. Time-dependent effects of AOX supplementation would be expected if changes in milk FA profile were mediated by gut microbiota, as 2 to $3 \mathrm{wk}$ is considered the required time to complete adaptation of ruminal microbes to dietary changes. Nevertheless, several studies have shown some short-term effects of 
vitamin E supplementation on milk FA profile (Pottier et al., 2006; Liu et al., 2008), even after 1 wk of supplementation (Zened et al., 2012).

On the other hand, in longitudinal experiments, stage of lactation may also affect milk composition, as energy balance, milk yield, gland structure, and hormonal status - and hence the potential response to AOX supplementation - change as lactation progresses (Ceballos et al., 2009; De La Fuente et al., 2009; Stoop et al., 2009; Mann et al., 2016). Nevertheless, the present experiment was carried out in mid lactation with all animals always in positive energy balance, aiming to minimize the effects of DIM. In fact, milk yield was slightly affected during the experiment so that milk production and composition recorded in TDM glands were similar during periods 1 and 2 (Pulido et al., 2012).

\section{Plasma and Milk AOX Capacity}

Plasma total AOX capacity is an indicator of the oxidative status of the animal and can be enhanced by supranutritional levels of vitamin E and Se (Chauhan et al., 2014; Alhidary et al., 2015). Vitamin E acts as a lipid-soluble cellular AOX and free radical scavenger, protecting lipids against peroxidation (Miller et al., 1993). Selenium is recognized as an essential trace element for farm animals and is a component of the glutathione peroxidase, which is responsible for the reduction of $\mathrm{H}_{2} \mathrm{O}_{2}$ and free $\mathrm{O}_{2}$ to $\mathrm{H}_{2} \mathrm{O}$. This mineral also plays a vital role in protecting both the intra- and extracellular lipid membranes against oxidative damage (Miller et al., 1993).

In the present study, the greater plasma AOX capacity observed in AOX ewes was probably related to the increased $\alpha$-tocopherol concentration in plasma because Se concentration in serum was unaffected by AOX supplementation. Likewise, both $\alpha$-tocopherol content and resistance to lipid oxidation were greater in milk from AOX ewes than from control ewes. These results agree with those of Focant et al. (1998), who observed an increase in milk resistance to oxidation when dairy cows fed a diet including oilseeds were orally supplemented with vitamin E. Fauteux et al. (2016) also reported a reduction in redox potential value and hexanal concentration in milk, both indicators of lipid oxidation, as a response to vitamin E supplementation. Pro-oxidative effects of tocopherol on milk fat may also occur, but in more unsaturated milk fat and with doses higher than that used in the current experiment (Slots et al., 2007).

Lipid peroxidation is increased when free FA and PUFA are increased in milk fat (Havemose et al., 2006), and it has been reported that ODM decreased milk lipoprotein lipase activity, and hence the content of free FA (Rémond et al., 2002; Chilliard et al., 2003; Komara et al., 2009), which could make milk more resistant to lipid peroxidation. However, we did not observe effects of MF on fat resistance to oxidation. As no differences were detected between ODM and TDM milk in SCFA or PUFA, it could be expected that MF had no effect on oxidative stability of milk fat.

\section{CONCLUSIONS}

Reducing MF to ODM did not affect milk oxidative stability but decreased the relative abundance of C16:0 and increased that of C18:0 and several C18:1 isomers, slightly increasing the proportion of total MUFA in milk. Dietary AOX supplementation did not affect the magnitude of the effects of milking only once daily. The combined supplementation of $\alpha$-tocopherol $(1,000 \mathrm{IU} / \mathrm{d})$ plus Se $(0.4 \mathrm{mg} / \mathrm{d})$ decreased the relative proportions of SCFA and medium-chain FA and increased that of LCFA in milk fat, in particular C16:0 and cis-9 C18:1, although these effects were moderate. Antioxidant supplementation also improved the oxidative status of dairy ewes and the AOX activity in milk, thus increasing the resistance of milk fat to oxidation.

\section{ACKNOWLEDGMENTS}

This work is part of a research project (ref. PI200440E549) of the Spanish National Research Council (CSIC, Madrid, Spain). Edgar Pulido received a scholarship for postgraduate studies from the University of Guadalajara, Mexico. The authors appreciate the collaboration of the Department of Food Safety and Technology of the University of Leon, Spain.

\section{REFERENCES}

Al-Mabruk, R. M., N. F. G. Beck, and R. J. Dewhurst. 2004. Effects of silage species and supplemental vitamin $\mathrm{E}$ on the oxidative stability of milk. J. Dairy Sci. 87:406-412.

Aldai, N., P. Lavín, J. K. Kramer, R. Jaroso, and A. R. Mantecón. 2012. Breed effect on quality veal production in mountain areas: Emphasis on meat fatty acid composition. Meat Sci. 92:687-696.

Alderson, N. E., J. R. Mitchell, G. E. Little, R. E. Warner, and R. E. Tucker. 1971. Pre-intestinal disappearance of vitamin E in ruminants. J. Nutr. 101:655-659.

Alex, A. P., J. L. Collier, D. L. Hadsell, and R. J. Collier. 2015. Milk yield differences between $1 \times$ and $4 \times$ milking are associated with changes in mammary mitochondrial number and milk protein gene expression, but not mammary cell apoptosis or SOCS gene expression. J. Dairy Sci. 98:4439-4448.

Alhidary, I. A., S. Shini, R. A. M. Al Jassim, A. M. Abudabos, and J. B. Gaughan. 2015. Effects of selenium and vitamin E on performance, physiological response, and selenium balance in heatstressed sheep. J. Anim. Sci. 93:576-588. 
B'Hymer, C., and J. A. Caruso. 2006. Selenium speciation analysis using inductively coupled plasma-mass spectrometry. J. Chromatogr. A $1114: 1-20$

Bauman, D. E., and J. M. Griinari. 2001. Regulation and nutritional manipulation of milk fat: Low-fat milk syndrome. Livest. Prod. Sci. 70:15-29.

Bauman, D. E., and J. M. Griinari. 2003. Nutritional regulation of milk fat synthesis. Annu. Rev. Nutr. 23:203-227.

Bernier-Dodier, P., L. Delbecchi, G. F. Wagner, B. G. Talbot, and P. Lacasse. 2010. Effect of milking frequency on lactation persistency and mammary gland remodeling in mid-lactation cows. J. Dairy Sci. 93:555-564.

Berthelot, V., L. Broudiscou, and P. Schmidely. 2014. Effect of vitamin E supplementation on fatty acid composition of muscle and adipose tissues of indoor lambs with special attention on rumen-derived trans monounsaturated fatty acids. Meat Sci. 96:1281-1288.

Bionaz, M., and J. J. Loor. 2008. Gene networks driving bovine milk fat synthesis during the lactation cycle. BMC Genomics 9:366.

Boutinaud, M., L. Galio, V. Lollivier, L. Finot, S. Wiart, D. Esquerré, and E. Devinoy. 2013. Unilateral once daily milking locally induces different gene expression in both mammary tissue and milk epithelial cells revealing mammary remodeling. Physiol. Genomics 45:973-985.

Capper, J. L., R. G. Wilkinson, E. Kasapidou, S. E. Pattinson, A. M. Mackenzie, and L. A. Sinclair. 2005. The effect of dietary vitamin $\mathrm{E}$ and fatty acid supplementation of pregnant and lactating ewes on placental and mammary transfer of vitamin $\mathrm{E}$ to the lamb. Br. J. Nutr. 93:549-557.

Castillo, V., X. Such, G. Caja, R. Casals, E. Albanell, and A. A. K. Salama. 2008. Effect of milking interval on milk secretion and mammary tight junction permeability in dairy ewes. J. Dairy Sci. 91:2610-2619.

Ceballos, A., J. Sánchez, H. Stryhn, J. B. Montgomery, H. W. Barkema, and J. J. Wichtel. 2009. Meta-analysis of the effect of oral selenium supplementation on milk selenium concentration in cattle. J. Dairy Sci. 92:324-342.

Charmley, E., and J. W. G. Nicholson. 1994. Influence of dietary fat source on oxidative stability and fatty acid composition of milk from cows receiving a low or high level of dietary vitamin E. Can. J. Anim. Sci. 74:657-664.

Chauhan, S. S., P. Celi, B. J. Leury, I. J. Clarke, and F. R. Dunshea. 2014. Dietary antioxidants at supranutritional level improve oxidative status and reduce the negative effects of heat stress in sheep. J. Anim. Sci. 92:3364-3374.

Chauveau-Duriot, B., M. Doreau, P. Nozière, and B. Graulet. 2010. Simultaneous quantification of carotenoids, retinol and tocopherols in forages, bovine plasma and milk: Validation on a novel UPLC method. Anal. Bioanal. Chem. 397:777-790.

Chikunya, S., G. Demirel, M. Enser, J. D. Wood, R. G. Wilkinson, and L. A. Sinclair. 2004. Biohydrogenation of dietary n-3 PUFA and stability of ingested vitamin $\mathrm{E}$ in the rumen, and their effects on microbial activity in sheep. Br. J. Nutr. 91:539-550.

Chilliard, Y., A. Ferlay, J. Rouel, and G. Lamberet. 2003. A review of nutritional and physiological factors affecting goat milk lipid synthesis and lipolysis. J. Dairy Sci. 86:1751-1770.

Chilliard, Y., D. Pomiès, P. Pradel, and B. Rémond. 2006. Oncedaily milking does not change milk fatty acid profile in cows in equilibrated energy balance. Page 311 in Book of Abstracts of the 57th Annual Meeting of the European Association for Animal Production, Antalya, Turkey. Wageningen Academic Publishers, Wageningen, the Netherlands.

Chilliard, Y. D., A. Ferlay, R. M. Mansbridge, and M. Doreau. 2000. Ruminant milk fat plasticity: Nutritional control of saturated, polyunsaturated, trans and conjugated fatty acids. Ann. Zootech. 49:181-205.

Cristaldi, L. A., L. R. McDowell, C. D. Buergelt, P. A. Davis, N. S. Wilkinson, and F. G. Martin. 2005. Tolerance of inorganic selenium in wether sheep. Small Rumin. Res. 56:205-213.

Davis, P. A., L. R. McDowell, N. S. Wilkinson, C. D. Buergelt, R. Van Alstyne, R. N. Weldon, T. T. Marshall, and E. Y. Matsuda-
Fugisaki. 2008. Comparative effects of various dietary levels of Se as sodium selenite or Se yeast on blood, wool, and tissue Se concentrations of wether sheep. Small Rumin. Res. 74:149-158.

De La Fuente, L. F., E. Barbosa, J. A. Carriedo, C. Gonzalo, R. Arenas, J. M. Fresno, and F. San Primitivo. 2009. Factors influencing variation of fatty acid content in ovine milk. J. Dairy Sci. 92:3791-3799.

Delamaire, E., and J. Guinard-Flament. 2006. Longer milking intervals alter mammary epithelial permeability and the udder's ability to extract nutrients. J. Dairy Sci. 89:2007-2016.

Dutreuil, M., J. Guinard-Flament, M. Boutinaud, and C. Hurtaud. 2016. Effect of duration of milk accumulation in the udder on milk composition, especially on milk fat globule. J. Dairy Sci. 99:3934-3944.

Farr, V. C., K. Stelwagen, M. A. Kerr, S. R. Davis, and S. J. Eichler. 1995. Effect of once daily milking (ODM) on enzyme activities in the bovine mammary gland. Proc. N.Z. Soc. Anim. Prod. 55:12-13.

Fauteux, M. C., R. Gervais, D. E. Rico, Y. Lebeuf, and P. Y. Chouinard. 2016. Production, composition, and oxidative stability of milk highly enriched in polyunsaturated fatty acids from dairy cows fed alfalfa protein concentrate or supplemental vitamin E. J. Dairy Sci. 99:4411-4426.

Feng, S., A. L. Lock, and P. C. Garnsworthy. 2004. Technical note: A rapid lipid separation method for determining fatty acid composition of milk. J. Dairy Sci. 87:3785-3788.

Ferneborg, S., L. Kovac, K. J. Shingfield, and S. Agenäs. 2017. Effect of increased milking frequency and residual milk removal on milk production and milk fatty acid composition in lactating cows. J. Dairy Res. 84:453-463.

Firestone, D. 2011. Official Methods and Recommended Practices of the AOCS. 6th ed. AOCS, Urbana, IL.

Focant, M., E. Mignolet, M. Marique, F. Clabots, T. Breyne, D. Dalemans, and Y. Larondelle. 1998. The effect of vitamin E supplementation of cow diets containing rapeseed and linseed on the prevention of milk fat oxidation. J. Dairy Sci. 81:1095-1101.

Galloway, P., D. C. McMillan, and N. Sattar. 2000. Effect of the inflammatory response on trace element and vitamin status. Ann. Clin. Biochem. 37:289-297.

Givens, D. I., R. Allison, B. Cottrill, and J. S. Blake. 2004. Enhancing the selenium content of bovine milk through alteration of the form and concentration of selenium in the diet of dairy cows. J. Sci. Food Agric. 84:811-817

Gómez-Cortés, P.. P. Frutos, A. R. Mantecón, M. Juárez, M. A. de la Fuente, and G. Hervás. 2008. Addition of olive oil to dairy ewe diets: Effect on milk fatty acid profile and animal performance. J. Dairy Sci. 91:3119-3127.

Guinard-Flament, J., E. Delamaire, P. Lamberton, and J. L. Peyraud. 2007. Adaptations of mammary uptake and nutrient use to once-daily milking and feed restriction in dairy cows. J. Dairy Sci. 90:5062-5072.

Guinard-Flament, J., S. Lemosquet, E. Delamaire, G. Le Bris, P. Lamberton, and C. Hurtaud. 2011. Alteration of the nutrient uptake by the udder over an extended milking interval. J. Dairy Sci. 94:5458-5468.

Havemose, M. S., M. R. Weisbjerg, W. L. Bredie, H. D. Poulsen, and J. H. Nielsen. 2006. Oxidative stability of milk influenced by fatty acids, antioxidants, and copper derived from feed. J. Dairy Sci. 89:1970-1980.

Hervás, G., J. L. Ramella, S. López, J. S. González, and A. R. Mantecón. 2006. Effect of omitting one or two milkings weekly on lactational performance in dairy ewes. J. Dairy Res. 73:207-215.

Hill, K. E., A. K. Motley, V. P. Winfrey, and R. F. Burk. 2014. Selenoprotein $\mathrm{P}$ is the major selenium transport protein in mouse milk. PLoS One 9:e103486.

Hillerton, J. E., C. H. Knight, A. Turvey, S. D. Wheatley, and C. J. Wilde. 1990. Milk yield and mammary function in dairy cows milked four times daily. J. Dairy Res. 57:285-294.

ISO/IDF (International Organization for Standardization/International Dairy Federation). 2002. Milk fat preparation of fatty acid methyl esters. International standard ISO 15884/IDF 182:2002. 
International Organization for Standardization, Geneva, Switzerland.

Khodamoradi, S., F. Fatahnia, K. Taherpour, V. Pirani, L. Rashidi, and A. Azarfar. 2013. Effect of monensin and vitamin E on milk production and composition of lactating dairy cows. J. Anim. Physiol. Anim. Nutr. (Berl.) 97:666-674.

Komara, M., M. Boutinaud, H. Ben Chedly, J. Guinard-Flament, and P. G. Marnet. 2009. Once-daily milking effects in high-yielding Alpine dairy goats. J. Dairy Sci. 92:5447-5455.

Krukovsky, V. N., and J. K. Loosli. 1952. Further studies on the influence of tocopherol supplementation on the vitamin content of the milk fat, stability of milk and milk and fat production. J. Dairy Sci. 35:834-838.

Kumar, N., A. K. Garg, V. Mudgal, R. S. Dass, V. K. Chaturvedi, and V. P. Varshney. 2008. Effect of different levels of selenium supplementation on growth rate, nutrient utilization, blood metabolic profile, and immune response in lambs. Biol. Trace Elem. Res. 126(Suppl. 1):S44-S56.

Lakic, B., K. M. Svennersten-Sjaunja, L. Norell, J. Dernfalk, and K. Ostensson. 2011. Effects of a single prolonged milking interval on inflammatory parameters, milk composition and yield in dairy cows. Vet. Immunol. Immunopathol. 140:110-118.

Liesegang, A., T. Staub, B. Wichert, M. Wanner, and M. Kreuzer. 2008. Effect of vitamin E supplementation of sheep and goats fed diets supplemented with polyunsaturated fatty acids and low in Se. J. Anim. Physiol. Anim. Nutr. (Berl.) 92:292-302.

Lindman, S. 2014. The effect of rapeseed oil and palm oil supplement and milking frequency on milk yield and milk fat quality. MS Thesis. Swedish University of Agricultural Sciences, Uppsala, Sweden.

Lindmark-Månsson, H., and B. Akesson. 2000. Antioxidative factors in milk. Br. J. Nutr. 84(Suppl. 1):S103-S110.

Liu, K., S. Ge, H. Luo, D. Yue, and L. Yan. 2013. Effects of dietary vitamin $\mathrm{E}$ on muscle vitamin $\mathrm{E}$ and fatty acid content in Aohan fine-wool sheep. J. Anim. Sci. Biotechnol. 4:21.

Liu, Z. L., D. P. Yang, P. Chen, W. X. Dong, and D. M. Wang. 2008. Supplementation with selenium and vitamin E improves milk fat depression and fatty acid composition in dairy cows fed fat diet. Asian-australas. J. Anim. Sci. 21:838-844.

Loften, J. R., J. G. Linn, J. K. Drackley, T. C. Jenkins, C. G. Soderholm, and A. F. Kertz. 2014. Invited review: Palmitic and stearic acid metabolism in lactating dairy cows. J. Dairy Sci. 97:46614674.

Luna, P., M. Juárez, and M. A. de la Fuente. 2005. Validation of a rapid milk fat separation method to determine the fatty acid profile by gas chromatography. J. Dairy Sci. 88:3377-3381.

Mann, S., U. K. Shandilya, M. Sodhi, P. Kumar, V. K. Bharti, P. Verma, A. Sharma, A. Mohanty, and M. Mukesh. 2016. Determination of antioxidant capacity and free radical scavenging activity of milk from native cows (Bos indicus), exotic cows (Bos taurus), and riverine buffaloes (Bubalus bubalis) across different lactation stages. Int. J. Dairy Sci. Process. 3:66-70.

Manso, T., B. Gallardo, A. Salvá, C. Guerra-Rivas, A. R. Mantecón, P. Lavín, and M. A. de la Fuente. 2016. Influence of dietary grape pomace combined with linseed oil on fatty acid profile and milk composition. J. Dairy Sci. 99:1111-1120.

Marnet, P. G., and B. C. McKusick. 2001. Regulation of milk ejection and milkability in small ruminants. Livest. Prod. Sci. 70:125-133.

McDowell, L. R., S. N. Williams, N. Hidiroglou, C. A. Njeru, G. M. Hill, L. Ochoa, and N. S. Wilkinson. 1996. Vitamin E supplementation for the ruminant. Anim. Feed Sci. Technol. 60:273-296.

Miller, J. K., E. Brzezinska-Slebodzinska, and F. C. Madsen. 1993. Oxidative stress, antioxidants, and animal function. J. Dairy Sci. 76:2812-2823.

Mosley, E. E., G. L. Powell, M. B. Riley, and T. C. Jenkins. 2002. Microbial biohydrogenation of oleic acid to trans isomers in vitro. J. Lipid Res. 43:290-296.

National Research Council. 1985. Nutrient Requirements of Sheep. 6th rev. ed. Natl. Acad. Sci., Washington, DC.

Nudda, A., I. R. Bencini, S. Mijatovic, and G. Pulina. 2002. The yield and composition of milk in Sarda, Awassi, and Merino sheep milked unilaterally at different frequencies. J. Dairy Sci. 85:28792884.

O'Donnell-Megaro, A. M., J. L. Capper, W. P. Weiss, and D. E. Bauman. 2012. Effect of linoleic acid and dietary vitamin E supplementation on sustained conjugated linoleic acid production in milk fat from dairy cows. J. Dairy Sci. 95:7299-7307.

O’Driscoll, K., G. Olmos, S. Llamas Moya, J. F. Mee, B. Earley, D. Gleeson, B. O'Brien, and L. Boyle. 2012. A reduction in milking frequency and feed allowance improves dairy cow immune status. J. Dairy Sci. 95:1177-1187.

Piantoni, P., P. Wang, J. K. Drackley, W. L. Hurley, and J. J. Loor 2010. Expression of metabolic, tissue remodeling, oxidative stress, and inflammatory pathways in mammary tissue during involution in lactating dairy cows. Bioinform. Biol. Insights 4:85-97.

Politis, I. 2012. Reevaluation of vitamin E supplementation of dairy cows: Bioavailability, animal health and milk quality. Animal $6: 1427-1434$.

Pottier, J., M. Focant, C. Debier, G. de Buysser, C. Goffe, E. Mignolet, E. Froidmont, and Y. Larondelle. 2006. Effect of dietary vitamin $\mathrm{E}$ on rumen biohydrogenation pathways and milk fat depression in dairy cows fed high-fat diets. J. Dairy Sci. 89:685-692.

Prieto, N., R. Bodas, O. López-Campos, S. Andrés, S. López, and F. J. Giráldez. 2013. Effect of sunflower oil supplementation and milking frequency reduction on sheep milk production and composition. J. Anim. Sci. 91:446-454.

Pulido, E., F. J. Giráldez, R. Bodas, S. Andrés, and N. Prieto. 2012. Effect of reduction of milking frequency and supplementation of vitamin $\mathrm{E}$ and Se above requirements on milk yield and composition in Assaf ewes. J. Dairy Sci. 95:3527-3535.

Re, R., N. Pellegrini, A. Proteggente, A. Pannala, M. Yang, and C. Rice-Evans. 1999. Antioxidant activity applying an improved ABTS radical cation decolorization assay. Free Radic. Biol. Med. $26: 1231-1237$

Rémond, B., S. Aubailly, Y. Chilliard, D. Dupont, D. Pomiès, and M. Petit. 2002. Combined effects of once-daily milking and feeding level in early lactation on production and enzyme activities of milk, and nutritional status, in Holstein cows. Anim. Res. 51:101-117.

Savoini, G., G. Farina, V. Dell'Orto, and D. Cattaneo. 2016. Through ruminant nutrition to human health. Adv. Anim. Biosci. 7:200207.

Shields, S. L., P. Rezamand, D. L. Sevier, K. S. Seo, W. Price, and M. A. McGuire. 2011. Effects of increased milking frequency for the first 21 days postpartum on selected measures of mammary gland health, milk yield and milk composition. J. Dairy Res. 78:301-307.

Shingfield, K. J., M. Bonnet, and N. Scollan. 2013. Recent developments in altering the fatty acid composition of ruminant-derived foods. Animal 7:132-162.

Slots, T., L. H. Skibsted, and J. H. Nielsen. 2007. The difference in transfer of all-rac-alpha-tocopherol stereo-isomers to milk from cows and the effect on its oxidative stability. Int. Dairy J. 17:737745 .

Sordillo, L. M., and S. L. Aitken. 2009. Impact of oxidative stress on the health and immune function of dairy cattle. Vet. Immunol. Immunopathol. 128:104-109.

Stelwagen, K., C. V. C. Phyn, S. R. Davis, J. Guinard-Flament, D. Pomiès, J. R. Roche, and J. K. Kay. 2013. Invited review: Reduced milking frequency: Milk production and management implications. J. Dairy Sci. 96:3401-3413.

Stoop, W. M., H. Bovenhuis, J. M. L. Heck, and J. A. M. van Arendonk. 2009. Effects of lactation stage and energy status on milk fat composition of Holstein-Friesian cows. J. Dairy Sci. 92:1469-1478.

Stowe, H. D., and T. H. Herdt. 1992. Clinical assessment of selenium status of livestock. J. Anim. Sci. 70:3928-3933.

Taheri, Z., S. Karimi, H. Mehrban, and A. Moharrery. 2018. Supplementation of different selenium sources during early lactation of native goats and their effects on nutrient digestibility, nitrogen and energy status. J. Appl. Anim. Res. 46:64-68.

Tsiplakou, E., C. Mitsiopoulou, A. Mavrommatis, C. Karaiskou, E. G. Chronopoulou, G. Mavridis, K. Sotirakoglou, N. E. Labrou, and G. Zervas. 2018. Effect of under and overfeeding on sheep and goat 
milk and plasma enzymes activities related to oxidation. J. Anim. Physiol. Anim. Nutr. (Berl.) 102:e288-e298.

Tufarelli, V., and V. Laudadio. 2011. Dietary supplementation with selenium and vitamin E improves milk yield, composition and rheological properties of dairy Jonica goats. J. Dairy Res. 78:144-148.

Vagni, S., F. Saccone, L. Pinotti, and A. Baldi. 2011. Vitamin E bioavailability: Past and present insights. Food Nutr. Sci. 2:10881096.

Van Ryssen, J. B. J., R. J. Coertze, and M. F. Smith. 2013. Timedependent effect of selenium on the relationship between selenium concentrations in whole blood and plasma of sheep. Small Rumin. Res. 112:85-90.

Vázquez-Añón, M., J. Nocek, G. Bowman, T. Hampton, C. Atwell, P. Vázquez, and T. Jenkins. 2008. Effects of feeding dietary antioxidant in diets with oxidized fat on lactation performance and antioxidant status of the cow. J. Dairy Sci. 91:3165-3172.

Vlaeminck, B., V. Fievez, A. R. J. Cabrita, A. J. M. Fonseca, and R. J. Dewhurst. 2016. Factors affecting odd- and branched-chain fatty acids in milk: A review. Anim. Feed Sci. Technol. 131:389-417.
Wallace, R. J., N. McKain, K. J. Shingfield, and E. Devillard. 2007. Isomers of conjugated linoleic acids are synthesized via different mechanism in ruminal digesta and bacteria. J. Lipid Res. 48:22472254.

Whanger, P. D., P. H. Weswig, and O. H. Muth. 1968. Metabolism of 75Se-selenite and 75Se-selenomethionine by rumen microorganism. Fed. Proc. 27:418.

Wiking, L., J. H. Nielsen, A. K. Bavius, A. Edvardsson, and K. Svennersten-Sjaunja. 2006. Impact of milking frequencies on the level of free fatty acids in milk, fat globule size and fatty acid composition. J. Dairy Sci. 89:1004-1009.

Wilde, C. J., and C. H. Knight. 1990. Milk yield and mammary function in goats during and after once-daily milking. J. Dairy Res. $57: 441-447$.

Zened, A., A. Troegeler-Meynadier, T. Najar, and F. Enjalbert. 2012. Effects of oil and natural or synthetic vitamin $\mathrm{E}$ on ruminal and milk fatty acid profiles in cows receiving a high-starch diet. J. Dairy Sci. 95:5916-5926. 